\title{
Sex ratio, reproduction, and growth of the gilthead sea bream, Sparus aurata (Pisces: Sparidae), in the Gulf of Gabes, Tunisia
}

\section{Proporción de sexos, reproducción y crecimiento de la dorada, Sparus aurata (Pisces: Sparidae), en el golfo de Gabes, Túnez}

\author{
Aymen Hadj-Taieb*, Mohamed Ghorbel, Nader Ben Hadj-Hamida, Othman Jarboui \\ Institut National des Sciences et Technologies de la Mer (INSTM), BP 1035, 3018 Sfax, Tunisia. \\ * Corresponding author. E-mail: aymen.haj.82@gmail.com
}

\begin{abstract}
Samples $(N=1065)$ of the gilthead seabream, Sparus aurata, were collected in the Gulf of Gabes (Tunisia) from March 2008 to February 2010. This species is a protandric hermaphrodite. Total length (TL) ranged from 10.10 to $35.00 \mathrm{~cm}$ and the number of males to each female was 1.18:1. The reproductive season extended from October to February and maximum spawning activity occurred from December to January. The size at which $50 \%$ of the males reached maturity was $17.63 \pm 0.28 \mathrm{~cm} \mathrm{TL}$ and the size at which $50 \%$ of males transformed into females was $18.75 \pm 0.19 \mathrm{~cm}$ TL. The length-weight relationship for all individuals was described by the following parameters: $a=0.0107$ and $b=3.0797$. Age of fish ranged from 0 to 8 years. Estimates of the von Bertalanffy growth parameters for the whole sample were: $L_{\infty}=$ $38.28 \mathrm{~cm}, k=0.202$ year $^{-1}$, and $t_{0}=-1.888$ years.
\end{abstract}

Key words: Sparus aurata, reproductive parameters, age, growth, Gulf of Gabes.

RESUMEN. Se recolectaron muestras $(N=1065)$ de la dorada, Sparus aurata, en el golfo de Gabes (Túnez) de marzo de 2008 a febrero de 2010. Esta especie es una hermafrodita protándrica. La longitud total (LT) varió de 10.10 a $35.00 \mathrm{~cm}$ y el número de machos por cada hembra fue de 1.18:1. La temporada reproductiva se extendió de octubre a febrero y la máxima actividad reproductiva se presentó de diciembre a enero. La talla a la cual el $50 \%$ de los machos alcanzó la madurez sexual fue de $17.63 \pm 0.28 \mathrm{~cm}$ LT y el tamaño al cual el $50 \%$ de los machos se transformó en hembras fue de $18.75 \pm 0.19 \mathrm{~cm}$ LT. La relación longitud-peso para todos los individuos fue descrita por los siguientes parámetros: $a=0.0107$ y $b=3.0797$. Se encontraron peces de 0 a 8 años de edad. Las estimaciones de los parámetros de crecimiento de von Bertalanffy para toda la muestra fueron: $L_{\infty}=38.28 \mathrm{~cm}, k=0.202 \mathrm{año}^{-1} \mathrm{y} t_{0}=-1.888$ años.

Palabras clave: Sparus aurata, parámetros reproductivos, edad, crecimiento, golfo de Gabes

\section{INTRODUCTION}

The gilthead seabream, Sparus aurata (Linnaeus 1758), is common in the Mediterranean Sea but rare in the Black Sea (Bânârescu 1964). It is also present in the northeastern Atlantic Ocean, from the British Isles to the Canaries and Cape Verde (Bauchot and Hureau 1986). There have been several studies on wild populations in the Atlantic Ocean (Arias 1980, Pita et al. 2002) and the Mediterranean Sea (Arnal et al. 1976, Lasserre 1976, Suau and López 1976, Ferrari and Chieregato 1981, Wassef and Eisawy 1985, Rosecchi 1987, Kraljević and Dulciić 1997, Mehanna 2007). Moreover, considerable research effort has been exerted on the aquaculture of this species in Europe (Chatain 1997, Shields 2001).

Some biological aspects have been studied in Tunisian waters (Chauvet 1979, Ksouri 1981). In Tunisia, S. aurata is of great commercial interest both in traditional fisheries and in marine aquaculture. It represents more than $15 \%$ of sparid fishes landed in the area (the statistical office of the General Directorate for Fisheries and Aquaculture in Tunisia provided an annual mean estimate of $291 \mathrm{t}$ for 2010, 2011, and 2012).

\section{INTRODUCCIÓN}

La dorada, Sparus aurata (Linnaeus 1758), se encuentra comúnmente en el mar Mediterráneo pero con poca frecuencia en el mar Negro (Bânârescu 1964). También se encuentra en el océano Atlántico nororiental, desde las islas Británicas hasta las islas Canarias y Cabo Verde (Bauchot y Hureau 1986). Se han realizado varios estudios sobre las poblaciones silvestres en el océano Atlántico (Arias 1980, Pita et al. 2002) y el mar Mediterráneo (Arnal et al. 1976, Lasserre 1976, Suau y López 1976, Ferrari y Chieregato 1981, Wassef y Eisawy 1985, Rosecchi 1987, Kraljević y Dulĉić 1997, Mehanna 2007). Asimismo, se han dedicado considerables esfuerzos de investigación a su acuicultura en Europa (Chatain 1997, Shields 2001).

En Túnez, donde S. aurata es de gran interés comercial tanto para las pesquerías tradicionales como para la acuicultura marina, se han estudiado algunos aspectos biológicos (Chauvet 1979, Ksouri 1981). Esta especie representa más del 15\% de los peces espáridos capturados en la región (la oficina de estadística de la Dirección General de Pesca y Acuicultura de Túnez proporcionó una estimación media anual de captura de $291 \mathrm{t}$ para 2010, 2011 y 2012). 
Despite its commercial importance, little is known about the life history parameters of $S$. aurata in Tunisia in general and the Gulf of Gabes in particular. It is therefore essential to determine the reproductive strategy and growth of this sparid species in order to obtain a better understanding of its biology and a suitable evaluation of its population dynamics, and improve fishery management. The present study provides data on the reproductive biology, age structure, and growth rates of S. aurata in the Gulf of Gabes.

\section{MATERIAL AND METHODS}

A total of 1065 specimens of S. aurata were obtained by a random stratified sampling of commercial catches from different fishing ports of the Gulf of Gabes between March 2008 and February 2010. The Gulf of Gabes is situated on the southern coastline of Tunisia, spreading over a large area of about $750 \mathrm{~km}$ from Cape Kapoudia (35th parallel North) to the Tunisian-Libyan border (fig. 1). The species is currently caught in the area with longlines, trammel nets, and traditional traps known locally as cherfias. These traps are used in the southern part of the country and particularly around the Kerkennah islands where waters are shallow and the tidal range is important. These $V$-shaped structures (the tip is directed seaward) consist of vertical partitions built of palm leaves. An entrance at the apex of the V leads to several chambers where fish remain trapped during low tide.

For each fish, total length (TL) was measured to the nearest millimeter, and total weight (TW) and eviscerated weight $(\mathrm{EW})$ were measured to the nearest $0.1 \mathrm{~g}$. Sexes were distinguished after macroscopic observation of the gonads. Specimens were considered males (M) if they had only
A pesar de su importancia comercial, poco se sabe acerca de los parámetros de historia de vida de $S$. aurata en Túnez en general y en el golfo de Gabes en particular. Por lo tanto, es importante determinar la estrategia reproductiva y el crecimiento de esta especie espárida para obtener un mejor conocimiento de su biología y dinámica poblacional y mejorar la gestión pesquera. Este trabajo proporciona datos sobre la biología reproductiva, estructura de edades y tasa de crecimiento de S. aurata en el golfo de Gabes.

\section{MATERIALES Y MÉTODOS}

Se obtuvieron 1065 especímenes de S. aurata mediante un muestreo aleatorio estratificado de capturas comerciales en diferentes puertos del golfo de Gabes entre marzo de 2008 y febrero de 2010. El golfo de Gabes se localiza en la costa sur de Túnez y cubre un área grande de unos $750 \mathrm{~km}$ desde cabo Kapoudia (paralelo 35 Norte) hasta la frontera de Túnez con Libya (fig. 1). En esta zona la especie actualmente se captura con palangres, trasmallos y trampas tradicionales conocidas localmente como cherfias. Estas trampas son empleadas en la parte sur del país, especialmente alrededor de las islas Kerkennah donde las aguas son someras y el intervalo de marea is importante. Estas estructuras en forma de $V$ (con la punta hacia el mar) consisten de particiones construidas con hojas de palma. Una entrada en el ápice de la $V$ lleva a unos compartimientos donde quedan atrapados los peces durante la marea baja.

Para cada ejemplar, la longitud total (LT) se midió al milímetro más cercano, y el peso total (PT) y peso eviscerado (PE) se midieron con precisión de $0.1 \mathrm{~g}$. El sexo se determinó mediante observación macroscópica de las gónadas. Los

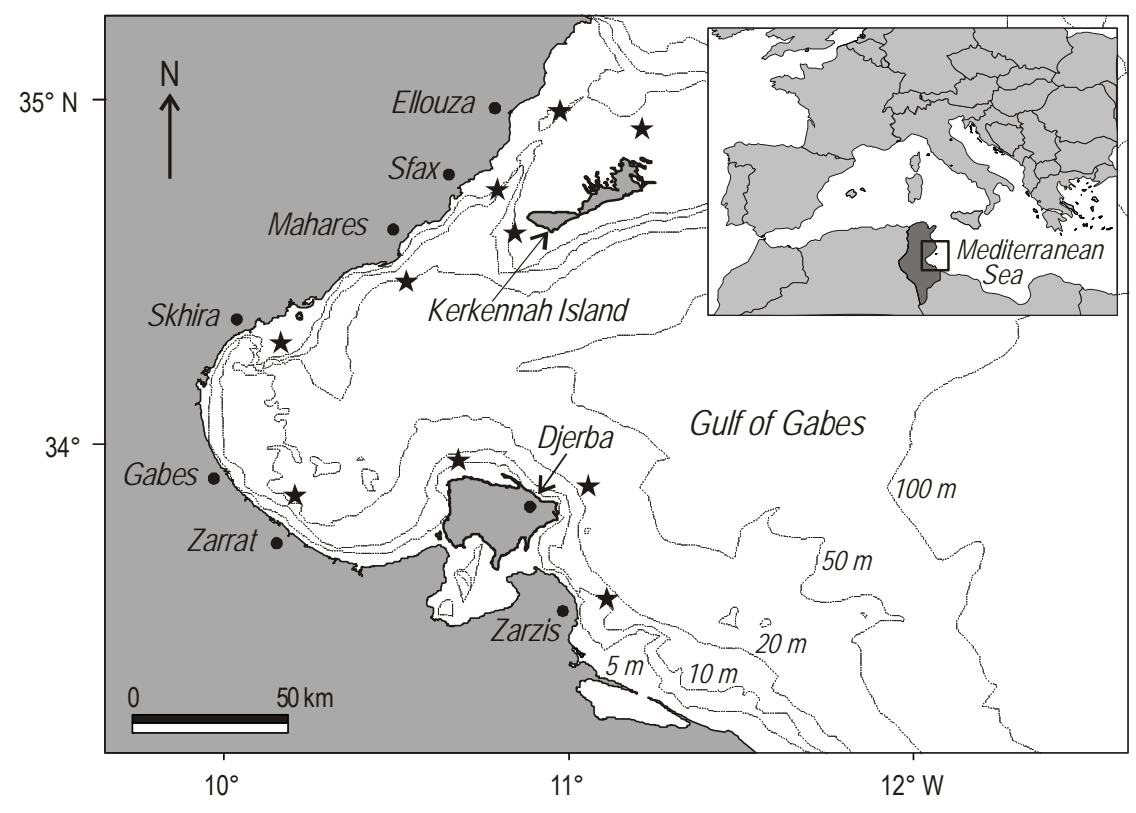

Figure 1. Geographical position of the Gulf of Gabes (Tunisia); stars, sampling area.

Figura 1. Posición geográfica del golfo de Gabes (Túnez); estrellas, zona de muestreo. 
testes, females (F) if they had only ovaries, and transitional individuals when male and female parts of the gonads occurred in equal or different proportions $(\mathrm{MF}=$ male and female tissues occurred in equal proportions, $\mathrm{Mf}=$ male tissue was predominant, and $\mathrm{Fm}=$ female tissue was predominant).

Maturity stages were determined macroscopically and gonad weight $(\mathrm{GW})$ was recorded to the nearest $0.01 \mathrm{~g}$. Maturity stages were classified as follows: I, immature; II, resting; III, ripe; IV, ripe and running; and V, spent (Holden and Raitt 1975).

The sex ratio (M:F) was analyzed by size classes. The spawning period was determined following the monthly changes in the gonadosomatic index (GSI), which was calculated as follows (Anderson and Gutreuter 1983):

$$
\mathrm{GSI}=\frac{(\mathrm{GW} \times 100)}{\mathrm{EW}}
$$

For the estimation of mean lengths at $50 \%$ maturity, a logistic function was fitted to the proportion of the mature individuals by size class using a nonlinear regression. The following function was used (Pauly 1980):

$$
P=\frac{1}{1+e^{-r\left(L-L_{50}\right)}}
$$

where $P$ is the proportion of mature fish in each size range $(L), L_{50}$ is the length at which $50 \%$ of the fish are mature, and $r$ is the constant.

A similar function was fitted to the percentage of the population made up of females to estimate the length at which $50 \%$ of the males in the population transformed into females $\left(P_{50}\right)$. The method proposed by Shapiro (1984), which consists of aggregating the length-frequency distribution where females and males overlap and then calculating the median of the distribution, was used to calculate the sexual inversion length.

With the sole aim of detecting whether there were signs of sexual inversion, we performed a histological examination of the gonads of seven transitional individuals of $S$. aurata selected randomly from the full size range $(17.8$ to $27 \mathrm{~cm})$ and for each maturity stage (ripe, ripe and running, and spent). Subsamples of gonadal tissues were fixed in Bouin's solution for two to three days and then dehydrated before being embedded in paraffin wax; after cutting, transverse sections of $5 \mu \mathrm{m}$ width were stained with hematoxylin and eosin. Reproductive phases and gamete stages were determined following Matsuyama et al. (1990) and Brown-Peterson et al. (2011).

The relation of total or eviscerated fish weight to total length was calculated applying the exponential regression equation (Ricker 1973): ejemplares se consideraron machos (M) si sólo presentaban testículos, hembras $(\mathrm{H})$ si sólo tenían ovarios, e individuos transicionales cuando presentaron componentes masculinos y femeninos en proporciones iguales o diferentes $(\mathrm{MH}=$ igual proporción de tejidos masculinos y femeninos, $\mathrm{Mh}=$ predominio de tejido masculino y $\mathrm{Hm}=$ predominio de tejido femenino).

Las etapas de madurez se determinaron macroscópicamente y el peso de las gónadas (PG) se registró con presición de $0.01 \mathrm{~g}$. Se clasificaron cinco etapas de madurez: I, inmaduro; II, en reposo; III, maduro; IV, maduro y fluyente; y V, evacuado (Holden y Raitt 1975).

La proporción de sexos (M:H) se analizó mediante clases de talla. El periodo de desove se determinó siguiendo los cambios mensuales en el índice gonadosomático (IGS), el cual se calculó como sigue (Anderson y Gutreuter 1983):

$$
\mathrm{IGS}=\frac{(\mathrm{PG} \times 100)}{\mathrm{PE}}
$$

Para la estimación de las longitudes promedio a 50\% de madurez sexual, se ajustó una función logística a la proporción de individuos maduros por clase de talla mediante una regresión no lineal. Se usó la siguiente función (Pauly 1980):

$$
P=\frac{1}{1+e^{-r\left(L-L_{50}\right)}}
$$

donde $P$ es la proporción de individuos maduros en cada intervalo de talla $(L), L_{50}$ es la longitud a la cual el $50 \%$ de los individuos alcanza la madurez sexual y $r$ es la constante.

Se ajustó una función similar al porcentaje de hembras en la población para estimar la longitud a la cual el 50\% de los machos de la población se transforman en hembras $\left(P_{50}\right)$. Para esto se utilizó el método de Shapiro (1984), el cual consiste en agregar la distribución de frecuencia de tallas donde las hembras y machos se traslapan y luego calcular el valor medio de la distribución.

Con la finalidad de detectar si existían signos de inversión sexual, se realizó un examen histológico de las gónadas de siete individuos transicionales de $S$. aurata escogidos aleatoriamente del intervalo completo de tallas $(17.8$ a $27 \mathrm{~cm})$ y de cada etapa de madurez (maduro, maduro y fluyente, y evacuado). Submuestras de los tejidos gonádicos fueron fijadas en solución de Bouin durante dos o tres días y luego deshidratadas y embebidas en parafina. Se cortaron secciones transversales de $5 \mu \mathrm{m}$ de grosor y se tiñieron con hematoxilina y eosina. Las fases reproductivas y de desarrollo de los gametos se determinaron según Matsuyama et al. (1990) y Brown-Peterson et al. (2011).

La relación entre el peso total o eviscerado y la longitud total de los peces se calculó usando la ecuación de regresión exponencial (Ricker 1973): 


$$
\mathrm{TW}\left(\text { or EW) }=a \mathrm{TL}^{b}\right.
$$

where $a$ and $b$ are the parameters to be estimated.

Otoliths (sagittae) were removed from 955 individuals and cleaned and stored for subsequent reading. Age was determined by reading the whole otolith under a compound binocular microscope at $20 \times$ magnification using reflected light while immersed in a solution of glycerine and alcohol. Age estimates were obtained by counting the number of opaque bands from the nucleus to the margin. As a rule, each otolith was read three times by the senior author, and readings for any given otolith were accepted only when two readings agreed. To determine the periodicity in the formation of the rings, the marginal increment method was applied. The method is based on estimates of marginal increment of the otolith of each fish per age class and estimates of the mean monthly marginal increment. The marginal increment $(0.1 \mathrm{~mm})$ was measured as the distance from the inner margin of the outermost translucent ring to the periphery of the otolith. Measurements were always made along the longest axis of the otolith. Owing to the wide range of ages encountered, it was necessary to combine the ages in groups to represent fast, moderate, and slow-growing individuals.

The von Bertalanffy growth curve was fitted to the observed length at each age of the resulting age-length key by means of Marquardt's algorithm for nonlinear least-squares parameter estimation (Saila et al. 1988). The equation for the growth curve is (Beverton and Holt 1957):

$$
L_{t}=L_{\infty}\left(1-e^{\left(t-t_{0}\right)}\right)
$$

where $L_{t}$ is the fish length at time $t$ (year), $L_{\infty}$ is the asymptotic length to which fish tend to grow, $k$ is the growth coefficient, and $t_{0}$ is the hypothetical time when fish length is zero.

We determined, through a direct calculation method (Jabeur 1999), the age for each fish length at the moment of capture. In this calculation we considered the spawning period, deposition of annual growth rings, as well as the date of capture of the individual considered.

\section{RESUlts}

Of the 1065 fish caught, 520 were males, 442 were females, and 76 were transitional individuals; the sex of the remaining 27 could not be determined macroscopically. Males ranged from 10 to $30 \mathrm{~cm}$ TL (11-200 g TW), females from 12 to $35 \mathrm{~cm}$ TL (20-350 g TW), and transitional individuals from 17 to $27 \mathrm{~cm} \mathrm{TL} \mathrm{(50-300} \mathrm{g} \mathrm{TW).}$

The sex ratio was biased in favor of males (M:F = $1.176: 1) ; \chi^{2}$ analysis showed that the number of males to each female was significantly different from a balanced ratio $(1: 1)\left(\chi^{2}=6.33, P<0.05\right)$. Males predominated in the smaller size classes and females in the larger ones (fig. 2).

$$
\mathrm{PT}(\mathrm{o} \mathrm{PE})=a \mathrm{LT}^{b}
$$

donde $a$ y $b$ son los parámetros a estimar.

Se extrajeron los otolitos (sagitas) de 955 individuos y se limpiaron y almacenaron para su posterior análisis. La edad se determinó leyendo el otolito entero (inmerso en una solución de glicerina y alcohol) usando un microscopio binocular con una magnificación de $20 \times$ y luz reflejada. Las estimaciones de edad se obtuvieron contando el número de bandas opacas del núcleo al margen. Los otolitos fueron leidos tres veces por el investigador principal y sólo se aceptaron las lecturas cuando dos coincidían. La periodicidad de formación de los anillos se determinó mediante el método de incremento marginal. Este método se basa en las estimaciones del incremento marginal del otolito de cada individuo por clase de edad y en las estimaciones del incremento marginal promedio mensual. El incremento marginal $(0.1 \mathrm{~mm})$ se midió como la distancia entre el margen interior del anillo translúcido más externo y la periferia del otolito. Las mediciones siempre se realizaron a lo largo del eje mayor del otolito. En vista del amplio intervalo de edades encontrado, fue necesario combinar las edades en grupos para representar individuos con crecimiento rápido, moderado y lento.

La curva de crecimiento de von Bertalanffy se ajustó a la longitud observada a cada edad de la clave de edad-longitud resultante mediante el algoritmo de Marquardt para la estimación por mínimos cuadrados de parámetros no lineales (Saila et al. 1988). La ecuación de la curva de crecimiento es (Beverton y Holt 1957):

$$
L_{t}=L_{\infty}\left(1-e^{\left(t-t_{0}\right)}\right)
$$

donde $L_{t}$ es la longitud del individuo en un tiempo $t$ (año), $L_{\infty}$ es la longitud asintótica que el individuo puede alcanzar, $k$ es el coeficient de crecimiento y $t_{0}$ es el tiempo hipotético cuando la longitud es cero.

Se estimó, mediante un método de cálculo directo (Jabeur 1999), la edad para cada longitud al momento de captura. Para este cálculo se consideró el periodo de desove, la deposición de anillos de crecimiento anuales y la fecha de captura del individuo examinado.

\section{RESUltados}

De los 1065 individuos capturados, 520 fueron machos, 442 fueron hembras y 76 fueron transicionales; no fue posible determinar macroscópicamente el sexo de los 27 restantes. Los machos variaron de 10 a $30 \mathrm{~cm}$ LT (11-200 g PT), las hembras de 12 a $35 \mathrm{~cm} \mathrm{LT} \mathrm{(20-350} \mathrm{g} \mathrm{PT)} \mathrm{y} \mathrm{los} \mathrm{individuos}$ transicionales de 17 a $27 \mathrm{~cm} \mathrm{TL}$ (50-300 g PT).

La proporción de sexos estuvo sesgada hacia los machos (M:H = 1.176:1); el análisis de $\chi^{2}$ mostró que el número de machos por cada hembra difirió significativamente de una 


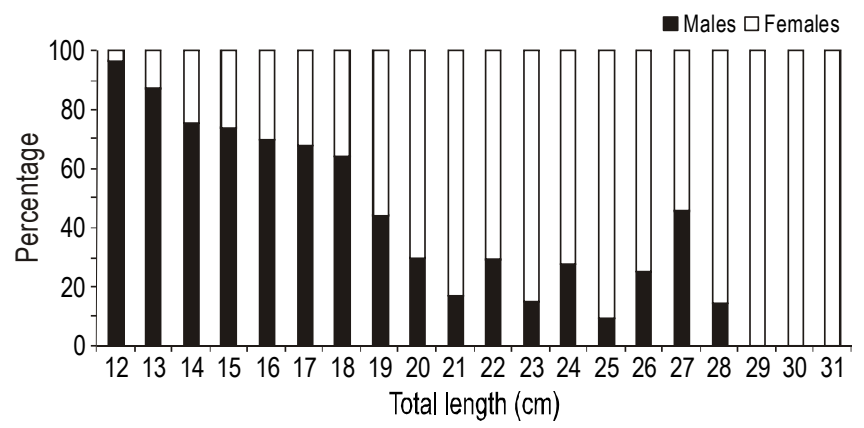

Figure 2. Length-frequency distribution of male and female Sparus aurata.

Figura 2. Distribución de la frecuencia de tallas de machos y hembras de Sparus aurata.

The transitional individuals (in the medium size classes) represented $7.10 \%$ of the specimens examined.

The observation of gonads with the naked eye revealed a small number of bisexual gonads (7.10\%), suggesting that S. aurata is hermaphroditic. These hermaphroditic specimens were mainly observed between October and February, during the reproduction period. Most of the time the gonads showed one sex as being more developed than the other, with a higher mean total length for the individuals with a more developed ovary (19 Mf: TL $=18.21 \pm 1.4 \mathrm{~cm} ; 21 \mathrm{MF}: \mathrm{TL}=20.32 \pm$ $0.7 \mathrm{~cm} ; 36 \mathrm{Fm}: \mathrm{TL}=23.86 \pm 3.5 \mathrm{~cm})$. The mean total length of the hermaphrodites as a whole was $21.47 \pm 0.6 \mathrm{~cm}$. Sexual inversion took place at approximately $18 \mathrm{~cm} \mathrm{TL}$, this being the median distribution of 1058 individuals ranging in size from 10 to $30 \mathrm{~cm}$.

The histological study of random gonad subsamples showed that all fishes showed bisexual gonads; however, the study of a small subsample allowed us to identify some gonads undergoing sexual inversion (fig. 3) and those were a real experimental indicator of sex change. They consisted of a developed ovarian portion containing pre-vitellogenic oocytes and a testicular portion in regression within which some residual spermatozoids betrayed a previous functional testis. The presence of individuals with well-formed ovaries and residues of degenerated testes confirms that $S$. aurata is a protandric hermaphrodite. Sex reversal was accompanied by resorption and restructuring of the testicular tissue and subsequent resurgence of the ovarian tissue.

The mean GSI values were usually higher for females than for males (fig. 4); however, they followed the same seasonal pattern. Mean GSI was higher from October to February, with a maximum between November and December. The maturation phase of gametes was observed between September and November. The maximum value of the mean GSI was observed in November, after which the values began to decrease, thus reflecting the phenomenon of spawning.

As shown in table 1 and in figure 5, male $L_{50}$ was $17.6 \pm$ $0.21 \mathrm{~cm}$ TL and $P_{50}$ was $18.75 \pm 0.19 \mathrm{~cm}$ TL.

The length-weight relationship parameters for males, females, and the two sexes considered together are presented proporción balanceada de 1:1 $\left(\chi^{2}=6.33, P<0.05\right)$. Los machos predominaron en las clases de talla menores y las hembras en las mayores (fig. 2). Los individuos transicionales (en las clases de talla medianas) representaron el 7.10\% de los especímenes examinados.

La observación de las gónadas a simple vista mostró un número pequeño de gónadas bisexuales $(7.10 \%)$, lo que sugiere que $S$. aurata es una especie hermafrodita. Los individuos transicionales se observaron principalmente entre octubre y febrero, durante el periodo reproductivo. La mayoría de las veces las gónadas mostraron un mayor desarrollo de un sexo que del otro, la longitud total promedio siendo mayor para los individuos con un ovario más desarrollado (19 Mh: $\mathrm{LT}=18.21 \pm 1.4 \mathrm{~cm} ; 21 \mathrm{MH}: \mathrm{LT}=20.32 \pm 0.7 \mathrm{~cm} ; 36 \mathrm{Hm}$ : $\mathrm{LT}=23.86 \pm 3.5 \mathrm{~cm}$ ). La longitud total promedio de los individuos transicionales en conjunto fue de $21.47 \pm 0.6 \mathrm{~cm}$. La inversión sexual sucedió a aproximadamente $18 \mathrm{~cm} \mathrm{LT}$, ésta siendo la distribución media de 1058 individuos variando de 10 a $30 \mathrm{~cm} \mathrm{LT}$.

El estudio histológico de las submuestras aleatorias de gónadas mostró que todos los individuos presentaron gónadas bisexuales; sin embargo, nos permitió identificar unas gónadas en proceso de inversión sexual (fig. 3), las cuales fueron un indicador experimental real del cambio de sexo. Consistieron de una porción ovárica desarrollada con ovocitos previtelogénicos y una porción testicular en regresión con algunos espermatozoides residuales mostrando evidencia de un testículo funcional anterior. La presencia de individuos con ovarios bien desarrollados y residuos de testículos degenerados confirma que $S$. aurata es una especie hermafrodita protándrica. La inversión sexual estuvo acompañada por la reabsorción y reestructuración del tejido testicular y posterior resurgimiento del tejido ovárico.

Los valores medios del IGS generalmente fueron mayores para las hembras que para los machos (fig. 4), pero mostraron el mismo patrón estacional, siendo mayores de octubre a febrero, con un máximo entre noviembre y diciembre. La etapa de maduración de los gametos se observó entre septiembre y noviembre. El valor máximo del IGS se observó en noviembre, después del cual los valores empezaron a decrecer, lo que refleja el fenómeno de desove.

Para los machos, $L_{50}=17.6 \pm 0.21 \mathrm{~cm} \mathrm{LT} \mathrm{y} P_{50}=18.75 \pm$ $0.19 \mathrm{~cm}$ LT (tabla 1, fig. 5).

Los parámetros de la relación longitud-peso para los machos, las hembras y los dos sexos en conjunto se presentan en la tabla 2. Se encontró una diferencia significativa en los coeficientes alométricos para machos y hembras $(t=5$, $P<0.05)$. Se observó un crecimiento alométrico positivo para las hembras y los dos sexos combinados, mientras que para los machos el peso aumentó isométricamente con la longitud (tabla 2).

Los anillos de crecimiento de los otolitos cubiertos de glicerina fueron visibles, pudiéndose leer el $82 \%$. El análisis del incremento marginal mostró que un solo anillo se formó durante mayo de cada año (fig. 6). 

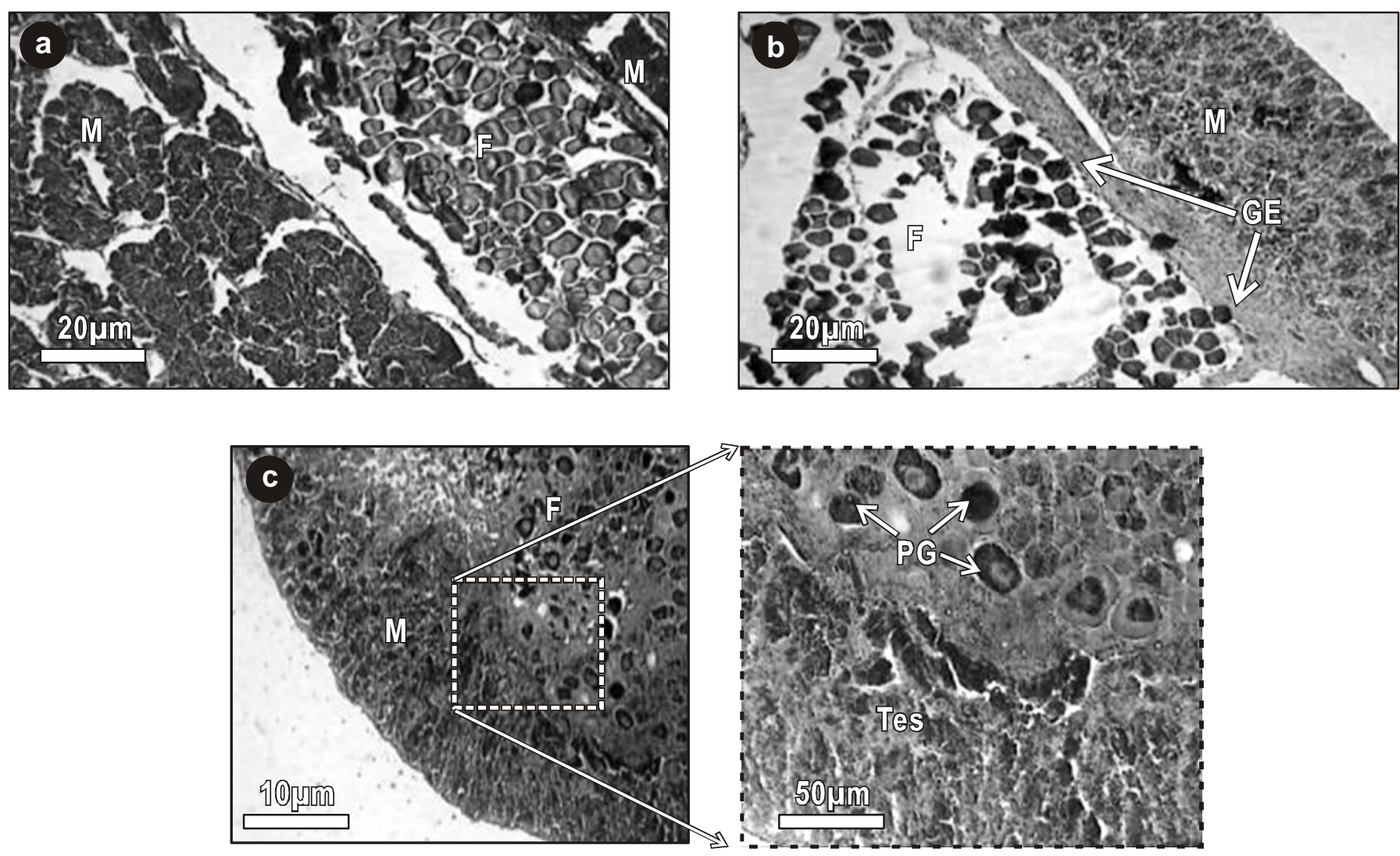

Figure 3. Histological images of gonadal tissue from hermaphrodite Sparus aurata collected off the south coast of Tunisia: (a) TL $=18.2 \mathrm{~cm}$, November 2009; (b) TL = 21.6 cm, December 2009; (c) TL = 23.4 cm, December 2009. M, male; F, female; GE, germinal epithelium; PG, oocyte undergoing primary growth; Tes, testis.

Figura 3. Imágenes histológicas de tejido gonadal de individuos hermafroditas de Sparus aurata recolectados en la costa sur de Túnez: (a) LT = $18.2 \mathrm{~cm}$, noviembre de 2009; (b) LT = $21.6 \mathrm{~cm}$, diciembre de 2009; (c) LT = $23.4 \mathrm{~cm}$, diciembre de 2009. M, macho; F, hembra; GE, epitelio germinal; PG, ovocito primario; Tes, testículo.

in table 2. A significant difference in the allometric coefficient was found between males and females $(t=5, P<0.05)$. Positive allometric growth was observed for females and all fish. For males, weight increased isometrically with length (table 2).

The otolith growth rings were clear when covered with glycerine, and $82 \%$ were readable. Marginal increment analysis showed that a single annulus was formed during May each year (fig. 6).

The length used in the age-length key (fig. 7, table 3) corresponded to averages of length calculated for individuals with the same age in months that we subsequently converted to years. Males ranged in age from $0+$ to $5+$ years and females from $0+$ to $7+$ years (table 3 , fig. 7). The parameters of the von Bertalanffy growth equation were: $L_{\infty}=38.28 \pm$ $4.19 \mathrm{~cm}, k=0.202$ year $^{-1} \pm 0.07$, and $t_{0}=-1.888 \pm 0.61$ year (table 4).

\section{DISCUSSION}

Sparus aurata is hermaphroditic (Bruslé-Sicard and Fourcault 1997). This characteristic, which is common
La longitud empleada en la clave de edad-longitud (fig. 7, tabla 3) correspondió a los promedios de la longitud estimada para los individuos de la misma edad en meses que subsecuentemente se conviertieron en años. La edad de los machos varió de $0+$ a 5+ años y la de las hembras de $0+$ a $7+$ años (tabla 3, fig. 7). Los parámetros de la ecuación de crecimiento de von Bertalanffy fueron: $L_{\infty}=38.28 \pm 4.19 \mathrm{~cm}$, $k=0.202$ año $^{-1} \pm 0.07$ y $t_{0}=-1.888 \pm 0.61$ años (tabla 4 ).

\section{DISCUSIÓN}

Sparus aurata es una especie hermafrodita (Bruslé-Sicard y Fourcault 1997). Esta característica, común entre espáridos (Alekseev 1982, Buxton y Garratt 1990), ha sido documentada para esta especie de otras zonas de la ribera sur del Mediterráneo (Chaoui et al. 2006, Mehanna 2007) y es reforzada en este estudio.

En el golfo de Gabes, la inversión sexual sucedió principalmente a $18 \mathrm{~cm}$ LT. Según Sadovy de Mitcheson y Liu (2008), la inversión sexual es acompañada por la reabsorción y reestructuración de las espermatogonias y el posterior resurgimiento del tejido ovárico. 


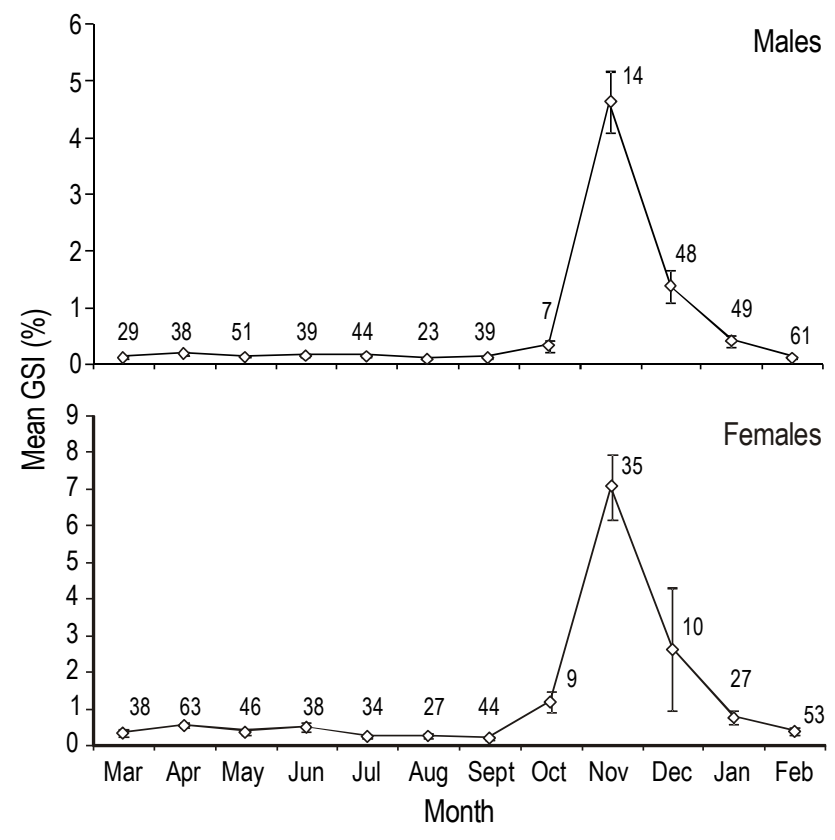

Figure 4. Monthly change in the mean gonadosomatic index (\%) for male and female Sparus aurata from the Gulf of Gabes. Vertical bars represent \pm 1 standard deviation.

Figura 4. Cambio mensual en el índice gonadosomático promedio (\%) para machos y hembras de Sparus aurata del golfo de Gabes. Las barras verticales representan \pm 1 desviación estándar.

among sparids (Alekseev 1982, Buxton and Garratt 1990), has also been observed for this species in other southern Mediterranean areas (Chaoui et al. 2006, Mehanna 2007) and is reinforced by our study.

In the Gulf of Gabes, sex transition occurred mainly at a size of $18 \mathrm{~cm}$ TL. According to Sadovy de Mitcheson and Liu (2008), sex reversal is accompanied by resorption and restructuring of spermatogonia and subsequent resurgence of the ovarian tissue.

The sex structure of the population, with a predominance of males over females, is mainly determined by the nature of the sexual change. Smale (1988) indicated that sex ratios of protandrous sparids tend to be skewed towards the males, as also observed in samples from elsewhere in the Mediterranean (Chaoui et al. 2006). Exploitation and expression of this type of hermaphroditism appear to be a response to a suite of environmental and biological factors (Sadovy de Mitcheson and Liu 2008). Such sex inversion, which is the change from one sex to another in a single individual, is a very common phenomenon in the family Sparidae (Buxton and Garratt 1990, Micale and Perdichizzi 1994, Vitale et al. 2011).

In the Atlantic, spawning occurs in the autumn and sometimes extends until early winter (Suau and López 1976). In the Mediterranean, S. aurata spawns from November to February (Lasserre and Labourg 1974, Chaoui et al. 2006), and this is supported by the present study in the Gulf of Gabes. Such an extensive spawning period could indicate
Table 1. Parameters of the sexual maturity ogive for male and female Sparus aurata from the Gulf of Gabes: $L_{50}$, length $(\mathrm{cm})$ at which $50 \%$ of the fish are mature; $P_{50}$, length at which $50 \%$ of the males transform into females; $r$, constant mean length of the interval; and $R^{2}$, coefficient of detemination.

Tabla 1. Parámetros de la ojiva de madurez sexual para machos y hembras de Sparus aurata del golfo de Gabes: $L_{50}$, longitud (cm) a la cual $50 \%$ de los individuos alcanzan la madurez sexual; $P_{50}$, longitud a la cual $50 \%$ de los machos se transforman en hembras; $r$, constante; y $R^{2}$, coeficiente de determinación.

\begin{tabular}{lcr}
\hline Parameter & Males & Females \\
\hline$L_{50}$ & 17.630 & \\
$P_{50}$ & & 18.750 \\
$r$ & 0.704 & 0.748 \\
$R^{2}$ & 0.984 & 0.992 \\
\hline
\end{tabular}
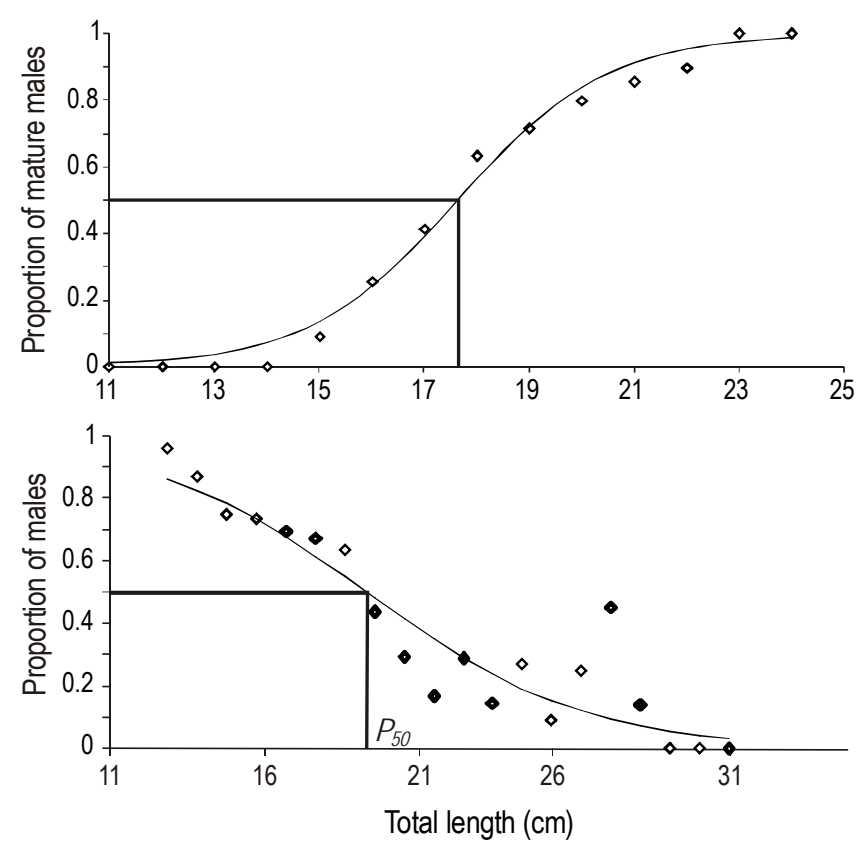

Figure 5. Logistic curve of the size at sexual maturity for male Sparus aurata and estimation of the length at which $50 \%$ of the males in the population transformed into females $\left(P_{50}\right)$ in the Gulf of Gabes.

Figura 5. Curva logística de la talla de madurez sexual para machos de Sparus aurata y estimación de la longitud a la cual el $50 \%$ de los machos en la población se transformaron en hembras $\left(P_{50}\right)$ en el golfo de Gabes.

La estructura sexual de la población, con predominancia de machos sobre hembras, se determina principalmente por la naturaleza de la inversión sexual. Smale (1988) indicó que las proporciones de sexos de espáridos protándricos pueden favorecer a los machos, como ha sido observado en muestras de otros lados del Mediterráneo (Chaoui et al. 2006). La explotación y expresión de este tipo de hermafroditismo 
Table 2. Length-weight relationships ( $\mathrm{TW}=a \mathrm{TL}^{b}$ and $\mathrm{EW}=a \mathrm{TL}^{b}$ ) for female, male, and all individuals of Sparus aurata from the Gulf of Gabes. TW, total fish weight; EW, eviscerated fish weight; $a$, intercept; $b$, slope; SD $b$, standard deviation of $b$; $R^{2}$, coefficient of determination; $n$, sample size; $t$, Student's $t$-test statistic.

Tabla 2. Relación longitud-peso ( $\mathrm{TW}=a \mathrm{TL}^{b}$ y EW $\left.=a \mathrm{TL}^{b}\right)$ para hembras, machos y el total de individuos de Sparus aurata del golfo de Gabes. TW, peso total; EW, peso eviscerado; $a$, intersección; $b$, pendiente; SD $b$, desviación estándar de $b$; $R^{2}$, coeficiente de determinación; $n$, tamaño de muestra; $t$, estadístico de la prueba $t$ de Student.

\begin{tabular}{lcccccccc}
\hline & & $a$ & $b$ & SD $b$ & $R^{2}$ & $n$ & $t$ & Allometry \\
\hline Females: & TW $(\mathrm{g})$ & 0.0077 & 3.1879 & 0.0670 & 0.9524 & 442 & 5.5320 & Majorant \\
& EW (g) & 0.0078 & 3.1600 & 0.0630 & 0.9563 & 442 & 4.9710 & Majorant \\
Males: & TW (g) & 0.0131 & 3.0081 & 0.0560 & 0.9553 & 520 & 0.2830 & Isometric \\
& EW (g) & 0.0110 & 3.0440 & 0.0500 & 0.9648 & 520 & 1.7210 & Isometric \\
All fish: & TW (g) & 0.0107 & 3.0797 & 0.0360 & 0.9632 & 1065 & 4.3170 & Majorant \\
& EW (g) & 0.0099 & 3.0826 & 0.0330 & 0.9689 & 1065 & 4.8780 & Majorant \\
\hline
\end{tabular}

that environmental conditions for hatching and larval development are favorable for a longer period (Tsikliras et al. 2010). An extensive spawning period has also been found for other sparid species in the same area, including Pagellus erythrinus (Ghorbel 1996) and Diplodus vulgaris (Hadj Taieb 2007).

Also, weight increases isometrically with length for the two sexes. Similar results have been reported from other areas (Wassef 1978).

The use of the von Bertalanffy model to describe growth has been criticized for several reasons (Booth 1997). Nevertheless, this model provides a simple description of growth that can be compared between species and species groups. The traditional or original form of the von Bertalanffy equation was chosen for this study because it contains fewer parameters than the Schnute growth model.

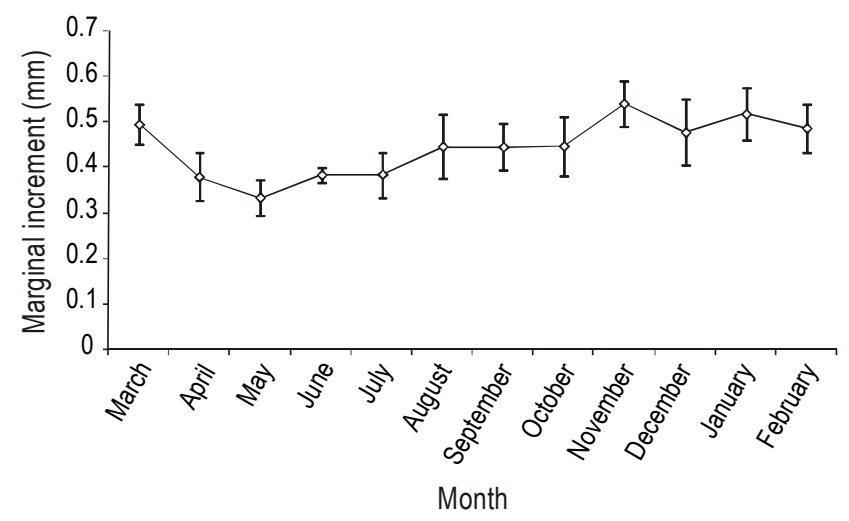

Figure 6. Monthly evolution of the marginal increment of otoliths of Sparus aurata in the Gulf of Gabes. Vertical bars represent \pm 1 standard deviation.

Figura 6. Evolución mensual del incremento marginal en los otolitos de Sparus aurata del golfo de Gabes. Las barras verticales representan \pm 1 desviación estándar. parecen ser una respuesta a varios factores ambientales y biológicos (Sadovy de Mitcheson y Liu 2008). Tal inversión sexual (i.e., el cambio de un sexo a otro en el mismo individuo) es un fenómeno común en la familia Sparidae (Buxton y Garratt 1990, Micale y Perdichizzi 1994, Vitale et al. 2011).

En el Atlántico, el desove se realiza en otoño y a veces se extiende hasta principios de invierno (Suau y López 1976). En el Mediterráneo, S. aurata desova de noviembre a febrero (Lasserre y Labourg 1974, Chaoui et al. 2006) y esto último es apoyado por lo observado en este estudio en el golfo de Gabes. Un periodo de desove tan extenso podría indicar que las condiciones ambientales para la eclosión y el desarrollo larval son favorables durante un mayor periodo de tiempo (Tsikliras et al. 2010). Un periodo de desove prolongado también ha sido documentado para otras especies de espáridos como Pagellus erythrinus (Ghorbel 1996) y Diplodus vulgaris (Hadj Taieb 2007).

Table 3. Parameters of the age-length key for all Sparus aurata individuals from the Gulf of Gabes.

Tabla 3. Parámetros de la clave de edad-longitud para todos los individuos de Sparus aurata del golfo de Gabes.

\begin{tabular}{cccc}
\hline $\begin{array}{c}\text { Age group } \\
\text { (years) }\end{array}$ & \multicolumn{3}{c}{ Size } \\
\cline { 2 - 4 } & Mean & Min. & Max. \\
\hline 0 & 14.86 & 14.20 & 15.50 \\
1 & 17.36 & 15.80 & 18.90 \\
2 & 20.42 & 19.10 & 25.50 \\
3 & 23.10 & 22.00 & 24.20 \\
4 & 25.12 & 24.40 & 26.00 \\
5 & 27.01 & 26.40 & 27.50 \\
6 & 28.24 & 28.20 & 28.30 \\
7 & 29.77 & 29.70 & 29.90 \\
\hline
\end{tabular}




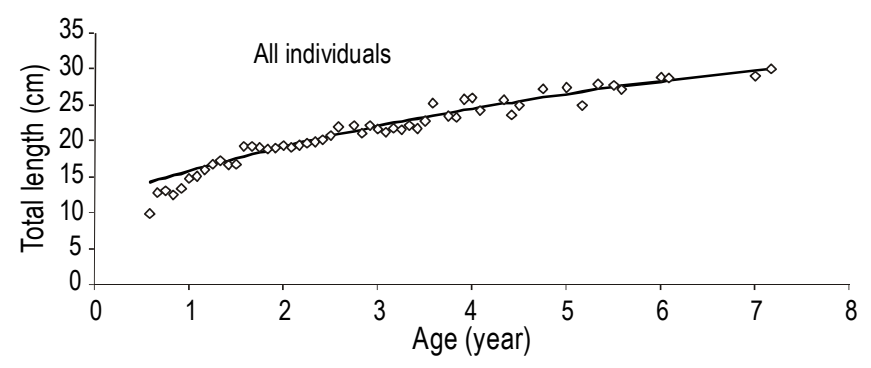

Figure 7. Von Bertalanffy growth curve for all Sparus aurata individuals in the Gulf of Gabes, derived from otolith readings.

Figura 7. Curva de crecimiento de von Bertalanffy para todos los individuos de Sparus aurata del golfo de Gabes, derivada de las lecturas de otolitos.

The oldest fish found in the Gulf of Gabes was 8 years old, while in Algeria it was 7 years (Chaoui et al. 2006) and in Egypt, 4 years (Mehanna 2007).

Differences in length between males and females of the same age cannot be considered as evidence of intersexual difference in growth rates because females and males are the same individuals at different phases of sexual succession and, possibly, the largest males in an age group are the first to change sex.

The theoretical maximum length value $(L=38.28 \mathrm{~cm})$ was close to the size of the largest fish examined, and the
Asimismo, el peso aumenta isométricamente con la longitud para ambos sexos. Se han obtenido resultados similares en otras zonas (Wassef 1978).

El uso del modelo de von Bertalanffy para decribir el crecimiento ha sido criticado por varias razones (Booth 1997). No obstante, este modelo proporciona una descripción simple del crecimiento que permite comparaciones entre especies y grupos de especies. Se escogió la forma original de la ecuación de von Bertalanffy para este estudio porque contiene menos parámetros que el modelo de crecimiento de Schnute.

El individuo de mayor edad encontrado en el golfo de Gabes fue de 8 años, mientras que en Algeria fue de 7 años (Chaoui et al. 2006) y en Egipto de 4 años (Mehanna 2007).

Una diferencia en longitud entre machos y hembras de la misma edad no puede considerarse evidencia de una diferencia intersexual de la tasa de crecimiento ya que las hembras y los machos son los mismos individuos en diferentes fases de sucesión sexual y, posiblemente, los machos de mayor tamaño de un grupo de edad son los primeros en cambiar de sexo.

El valor de longitud máxima teórica $(L=38.28 \mathrm{~cm})$ fue similar al tamaño del pez más grande examinado, y el valor del coeficiente de crecimiento $\left(k=0.202\right.$ año $\left.^{-1}\right)$ indicó una relativamente baja obtención de la talla máxima. Estos parámetros son similares a los obtenidos por Ameran (1992) y Tharwat et al. (1998) en Egipto (tabla 4; figs. 8, 9), pero

Table 4. Estimated parameters of the von Bertalanffy growth equation for combined sexes of Sparus aurata from different areas.

Tabla 4. Estimaciones de los parámetros de la ecuación de crecimiento de von Bertalanffy para los sexos combinados de Sparus aurata de diferentes áreas.

\begin{tabular}{|c|c|c|c|c|c|}
\hline $\mathrm{L} \infty(\mathrm{cm})$ & $k\left(\mathrm{yr}^{-1}\right)$ & $t_{0}($ year $)$ & Method & Area & Reference \\
\hline 62.02 & 0.222 & -0.774 & Scales & Thau (France) & Lasserre and Labourg (1974) \\
\hline 53.00 & 0.315 & - & $\mathrm{LFA}^{\mathrm{a}}$ & Segura (Spain) & Arnal et al. (1976) \\
\hline 53.48 & 0.264 & -1.340 & Scales & Graveyron (France) & Lasserre (1976) \\
\hline 62.19 & 0.171 & -0.531 & $\mathrm{LFA}^{\mathrm{a}}$ & Ebro (Spain) & Suau and López (1976) \\
\hline 70.62 & 0.170 & - & Scales & Alexandria (Egypt) & Wassef (1978) \\
\hline 84.55 & 0.130 & -1.586 & Scales & Cádiz (Spain) & Arias (1980) \\
\hline 38.05 & 0.250 & -1.920 & Scales & Bardawil Lagoon (Egypt) & Ameran (1992) \\
\hline 34.08 & 0.580 & -0.700 & Scales & Bardawil Lagoon (Egypt) & Abd-Allah (2004) \\
\hline 55.33 & 0.513 & -0.228 & Scales & Mellah Lagoon (Algeria) & Chaoui et al. (2006) \\
\hline 37.98 & 0.500 & -0.600 & Otoliths & Port Said (Egypt) & Mehanna (2007) \\
\hline 38.28 & 0.202 & -1.888 & Otoliths & Gulf of Gabes & Present study \\
\hline
\end{tabular}

${ }^{\mathrm{a}}$ LFA, length-frequency analysis. 


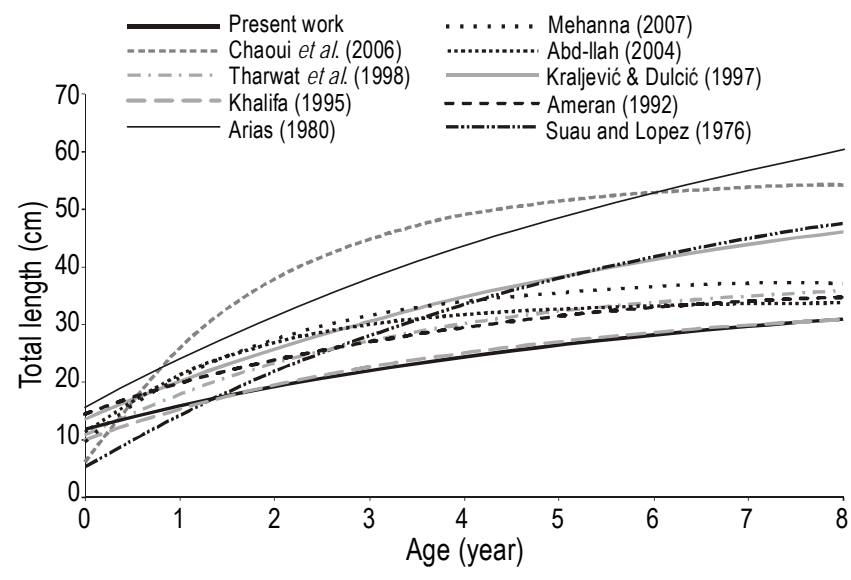

Figure 8. Total lengths by age for Sparus aurata according to several authors.

Figura 8. Longitud total por edad para Sparus aurata según varios autores.

growth coefficient value $\left(k=0.202\right.$ year $\left.^{-1}\right)$ indicated relatively low attainment of maximum size. These parameters are similar to those obtained by Ameran (1992) and Tharwat et al. (1998) in Egypt (table 4; figs. 8, 9); however, they differ from those obtained by Lasserre and Labourg (1974) in France, Suau and López (1976) in eastern Spain, Kraljević and Dulĉić (1997) in the northern Adriatic sea, and Chaoui et al. (2006) in Algeria (table 4, fig. 8). The differences in growth between regions can be attributed to the differences in the size of the largest individual sampled in each area, the methods used for assessing the growth equation, and the differences in the environmental conditions. The largest specimens were found in the studies conducted by Lasserre (1976), Wassef (1978), and Chaoui et al. (2006). The absence of large individuals in our study area might be explained by the phenomenon of migration.

In the Gulf of Gabes, S. aurata grows slower than in the eastern Mediterranean (Arnal et al. 1976, Suau and López 1976) and western Mediterranean (Khalifa 1995, Abd-Allah 2004). This phenomenon has been observed for other species such as the scorpion Scorpaena porcus (Bradai and Bouain 1988) and the common pandora Pagellus erythrinus (Ghorbel and Bouain 1990).

The growth parameters obtained in the present study are reasonable because the theoretical maximum length value is higher than the size of the largest fish sampled and the growth coefficient value indicates a relatively slow attainment of maximum size, characteristic of long life-cycle species. Individuals grow fast during their first immature year, attaining approximately $40 \%$ of the maximum length; after the first year, the annual growth rate drops rapidly.

\section{ACKNOWLEDEgMENTS}

Special thanks to the technical and supporting staff at INSTM (Sfax) for their assistance in laboratory analyses and

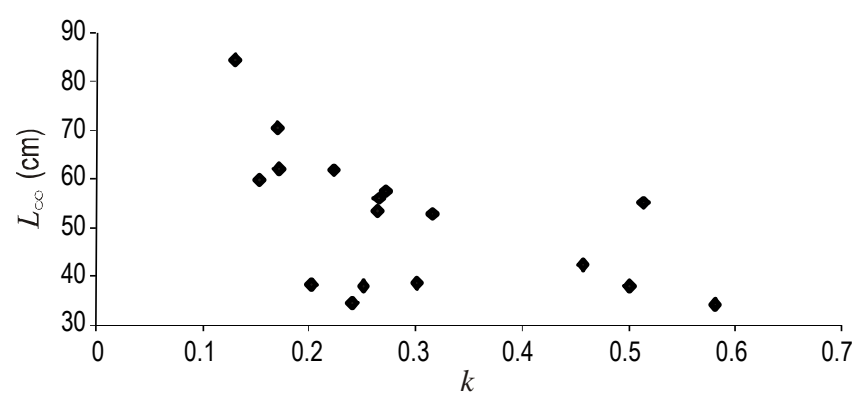

Figure 9. Distribution of Sparus aurata growth parameters $\left(L_{\infty}\right.$ and $k$ ) estimated from existing studies in different areas (table 4). Figura 9. Distribución de los parámetros de crecimiento $\left(L_{\infty} \mathrm{y} k\right)$ de Sparus aurata tomados de estudios previos en diferentes áreas (tabla 4).

difieren de los obtenidos por Lasserre y Labourg (1974) en Francia, Suau y López (1976) en el este de España, Kraljević y Dulĉić (1997) en el Adriático norte y Chaoui et al. (2006) en Algeria (tabla 4, fig. 8). La diferencia en crecimiento entre las regiones puede atribuirse a las diferencias en el tamaño del individuo más grande examinado en cada lugar, los métodos usados para evaluar la ecuación de crecimiento y las diferentes condiciones ambientales. Los especímenes más grandes se han encontrado en los estudios realizados por Lasserre (1976), Wassef (1978) y Chaoui et al. (2006). La ausencia de individuos grandes en nuestro estudio podría atribuirse al fenómeno de migración.

En el golfo de Gabes, S. aurata crece más lento que en el Mediterráneo oriental (Arnal et al. 1976, Suau y López 1976) y occidental (Khalifa 1995, Abd-Allah 2004). Este fenómeno ha sido documentado para otras especies como Scorpaena porcus (Bradai y Bouain 1988) y Pagellus erythrinus (Ghorbel y Bouain 1990).

Los parámetros de crecimiento obtenidos en el presente estudio son razonables ya que la longitud máxima teórica es mayor que el tamaño del pez más grande examinado y el valor del coeficiente de crecimiento indica una obtención relativamente lenta del tamaño máximo, lo cual es característico de especies que presentan ciclos de vida largos. Los individuos crecen rápidamente durante su primer año de inmadurez, alcanzando aproximadamente el $40 \%$ de su talla máxima; después del primer año, la tasa de crecimiento anual decrece rápidamente.

\section{Agradecimientos}

Se agradece al cuerpo técnico y de apoyo del INSTM (Sfax) su asistencia en el laboratorio y a Nabil Kallel (Facultad de Ciencias, Sfax) su revisión del manuscrito. Las sugerencias y comentarios de los revisores anónimos ayudaron a mejorar el manuscrito.

Traducido al español por Christine Harris. 
to Nabil Kallel (Faculty of Sciences, Sfax) for proof-reading our manuscript. The authors are also grateful to the anonymous reviewers whose suggestions and comments improved the submitted manuscript.

\section{REFERENCES}

Abd-Allah SM. 2004. Biological studies for the fishery regulations and management of the Bardawil Lagoon. PhD thesis, Suez Canal University, Egypt, 282 pp.

Alekseev FE. 1982. Hermaphroditism in sparid fishes (Perciformes: Sparidae). I. Protogyny in porgies, Pagrus pagrus, P. orphus, P. ehrenbergi and P. auriga, from West Africa. J. Ichthyol. 22: 85-94.

Ameran MA. 1992. Studies on fish production of Bardawil Lagoon. MSc thesis, Suez Canal University, Egypt, 158 pp.

Anderson RO, Gutreuter SJ. 1983. Length, weight, and associated structural indices. In: Nielsen LA, Jonhnson DL (eds.), Fisheries Techniques. American Fisheries Society, Bethesda, pp. 283-300.

Arias A. 1980. Crecimento, régimen alimentario y reproducción de la dorada (Sparus aurata L.) y del róbalo (Dicentrarchus labrax L.) en los esteros de Cádiz. Inv. Pesq. 44: 59-83.

Arnal JI, García-Alcazar A, Ortega A. 1976. Observaciones sobre el crecimento de la dorada (Sparus aurata L.) en el Mar Menor (Murcia). Bol. Inst. Esp. Oceanogr. 221: 1-17.

Bânârescu P. 1964. Fauna republicii populare romine (PisesOsteichthyes). Editura Academiei Republicii Populare Romine, Bucharest, $960 \mathrm{pp}$.

Bauchot ML, Hureau JC. 1986. Sparidae. In: Whitehead PJP, Bauchot ML, Hureau JC, Nielsen J, Tortenese E (eds.), Fishes of the North-Eastern Atlantic and Mediterranean. UNESCO, Paris, pp. 883-907.

Beverton RJH, Holt SJ. 1957. On the dynamics of exploited fish populations. Fishery Investigations Series II, XIX. HMSO, London, $533 \mathrm{pp}$.

Booth AJ. 1997. On the life history of lesser gurnard (Scorpaeniformes: Triglidae) inhabiting the Agulhas Bank, South Africa. J. Fish. Biol. 51: 1155-1173.

Bradai MN, Bouain A. 1988. Age et croissance de Scorpaena porcus et Scorpaena scorfa du golfe de Gabès. Bull. Inst. Nat. Scient. Tech. Océanogr, Pêche Salammbô 15: 13-38.

Brown-Peterson NJ, Wyansky DM, Saborido-Rey F, Macewicz BJ, Lowerre-Barbieri SK. 2011. A standardized terminology for describing reproductive development in fishes. Mar. Coast. Fish. 3: 52-70.

Bruslé-Sicard S, Fourcault B. 1997. Recognition of sex-inverting protandric Sparus aurata: Ultrastructural aspects. J. Fish Biol. 50: 1094-1103.

Buxton CD, Garratt PA. 1990. Alternative reproductive styles in seabreams (Pisces: Sparidae). Environ. Biol. Fish. 28: 113-124.

Chaoui L, Kara MH, Faure E, Quignard JP. 2006. Growth and reproduction of the gilthead seabream Sparus aurata in Mellah Lagoon (north-eastern Algeria). Scien. Mar. 70: 545-552.

Chatain B. 1997. Development and achievements of marine fishrearing technology in France over the last 15 years. Hydrobiologia 358: 7-11.

Chauvet C. 1979. Préliminaire à l'étude de la biologie et de la dynamique du stock tunisien de Sparus aurata (L. 1758). Synopsis de la croissance groupes $0,1,2$. Bull. Off. Nat. Pêches 3(2): 241-253.

Ferrari I, Chieregato AJ. 1981. Feeding habits of juvenile stages of Sparus auratus L., Dicentrarchus labrax L. and Mugilidae in a brackish embayment of the Po River delta. Aquaculture 25: 243-257.

Ghorbel M. 1996. Le pageot commun Pagellus erythrinus (Poissons, Sparidae): Ecobiologie et état d'exploitation dans le golfe de Gabès. PhD thesis, University of Sfax, Tunisia, 170 pp.

Ghorbel M, Bouain A. 1990. Age et croissance et croissance du pageot commun Pagellus erythrinus du golfe de Gabès, Tunisie. Bull. Inst. Nat. Scient. Tech. Océanogr. Pêche Salammbô 17: $17-32$.

Hadj Taieb A. 2007. Contribution a l'etude ecobiologique du sar à tête noire Diplodus vulgaris (Téleosteens, Sparidae) du golfe de Gabès. MSc thesis, University of Sfax, Tunisia, 96 pp.

Holden MJ, Raitt DFS. 1975. Manual de ciencia pesquera. Parte 2. Métodos para investigar los recursos y su aplicación. FAO Documentos Técnicos de Pesca 115, 211 pp.

Jabeur C. 1999. La pêche dans le golfe de Gabès: Interactions techniques entres les métiers et exploitation partagée du rouget rouge (Mullus surmuletus L., 1758). PhD thesis, Université de Bretagne Occidentale, France, 168 pp.

Khalifa U. 1995. Biological studies on gilthead bream, Sparus aurata in Lake Bardwil. MSc thesis, Cairo University, Egypt, $361 \mathrm{pp}$.

Kraljević M, Dulĉić J. 1997. Age and growth of gilt-head seabream (Sparus aurata L.) in the Mirna Estuary, northern Adriatic. Fish. Res. 31: 249-255.

Ksouri J. 1981. Contribution à l'étude de la biologie de S. aurata du golfe de Tunis et de son élevage dans les stations de Ghar EL Melh et Lakarit. MSc thesis, University of Tunis, Tunisia, $108 \mathrm{pp}$.

Lasserre G. 1976. Dynamique des populations ichthyologiques lagunaires. Application à Sparus aurata. $\mathrm{PhD}$ thesis, Université Montpellier II, France, 306 pp.

Lasserre G, Labourg PJ. 1974. Etude comparée de la croissance de la daurade Sparus aurata L. des régions d'Arcachon et de Sète. Vie Milieu 24: 155-170.

Matsuyama M, Adachi S, Nagahama Y, Maruyama K, Matsura S. 1990. Diurnal rhythm of serum steroid hormone levels in the Japanese whiting, Sillago japonica, a daily-spawning teleost. Fish Physiol. Biochem. 8: 329-338.

Mehanna SF. 2007. A preliminary assessment and management of gilthead bream Sparus aurata in the Port Said fishery, the southeastern Mediterranean, Egypt. Turkish J. Fish. Aquat. Sci. 7: $123-130$.

Micale V, Perdichizzi F. 1994. Further studies on the sexuality of the hermaphroditic teleost Diplodus sargus (L.). J. Fish Biol. 31: 435-440.

Pauly D. 1980. On the interrelationships between natural mortality, growth parameters, and mean environmental temperature in 175 fish stocks. J. Cons. Int. Exp. Mer 39:175-192.

Pita C, Gamito S, Erzini K. 2002. Feeding habits of the gilthead seabream (Sparus aurata) from the Ria Formosa (southern Portugal) as compared to the black seabream (Spondyliosoma cantharus) and the annular seabream (Diplodus annularis). J. Appl. Ichthyol. 18: 81-86.

Ricker WE. 1973. Linear regressions in fishery research. J. Fish. Res. Bd. Canada 30: 409-434.

Rosecchi E. 1987. L'alimentation de Diplodus annularis, Diplodus sargus, Diplodus vulgaris et Sparus aurata (Pisces, Sparidae) dans le golfe du Lion et les lagunes littorales. Rev. Trav. Inst. Pêches Marit. 49: 125-141.

Sadovy de Mitcheson Y, Liu M. 2008. Functional hermaphroditism in teleosts. Fish Fish. 9:1-43.

Saila SB, Recksiek CW, Prager MH. 1988. Basic fishery science programs. A compendium of microcomputer programs and manual of operation. Dev. Aquacult. Fish. Sci. 18: 1-230. 
Shapiro DY. 1984. Sex reversal and sociodemographic processes in coral reef fishes. In: Potts GW, Wootton RJ (eds.), Fish Reproduction: Strategies and Tactics. 3rd ed. Academic Press, London, pp. 103-118.

Shields RJ. 2001. Larviculture of marine finfish in Europe. Aquaculture 200: 55-88.

Smale MJ. 1988. Distribution and reproduction of the reef fish Petrus rupestris (Pisces: Sparidae) off the coast of South Africa. J. Zool. S. Afr. 23: 272-287.

Suau P, López J. 1976. Contribución al studio de la dorada, Sparus aurta L. Inv. Pesq. 40: 169-199.

Tharwat AA, Emam WM, Ameran MA. 1998. Stock assessment of the gilthead seabream Sparus aurata from Bardawil Lagoon, North Sinai, Egypt. J. Aquat. Biol. Fish. 2: 483-504.
Tsikliras AC, Antonopoulou E, Stergiou KI. 2010. Spawning period of Mediterranean marine fishes. Rev. Fish Biol. Fish. 20: 499-538.

Vitale S, Arkhipkin A, Cannizzaro L, Scalisi M. 2011. Life history traits of the striped seabream Lithognathus mormyrus (Pisces, Sparidae) from two coastal fishing grounds in the Strait of Sicily. J. Appl. Ichthyol. 27: 1086-1094.

Wassef E. 1978. Biological and physiological studies on marine and acclimatized fish Chrysophrys auratus. PhD thesis, Cairo University, Egypt, 225 pp.

Wassef EA, Eisawy A. 1985. Food and feeding habits of wild and reared gilthead bream Sparus aurata L. Cybium 9: 233-242.

Received April 2012,

received in revised form December 2012, accepted January 2013. 